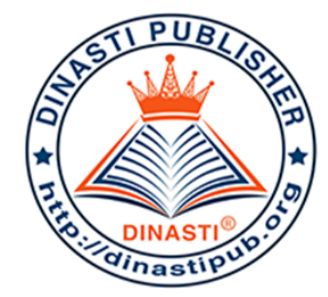

\title{
THE EFFECT OF WORKING CAPITAL, RETURN ON ASSETS AND COMPANY SIZES ON THE CREDIT AMOUNT OF SMALL AND MEDIUM MICRO BUSINESSES IN NATIONAL BANKS IN INDONESIA PRE COVID-19
}

\section{Deni Sunaryo}

Universitas Serang Raya, Banten, Indonesia

ARTICLE INFORMATION

Received: $1^{\text {st }}$ July 2020

Revised: $5^{\text {th }}$ August 2020

Issued: $14^{\text {th }}$ August 2020

Corresponding author: first author E-mail:

denisunaryomm@gmail.com

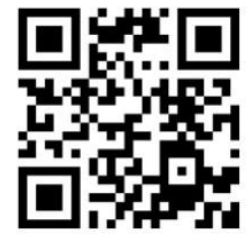

DOI:10.38035/DIJEFA
Abstract: The research of "Effect of Working Capital, Return on Assets and Company Size on the Amount of Micro and Small Medium Enterprises Loans at National Banks in Indonesia in Pra COVID-19" was conducted using Multiple Linear Regression analysis tools using the help of SPSS 25 data processing applications. This research is the influence of Working Capital variable on the distribution of MSME loans with $\mathrm{t}$ arithmetic $>\mathrm{t}$ table $(4.992>2.048)$ with a significance value of $0.000<0.05$. The Return on Assets (ROA) variable does not affect the distribution of MSME loans to national banks in Indonesia in 2014-2018 with $\mathrm{t}$ count $<\mathrm{t}$ table $(0.025<2.048)$ with a significance value of $0.980>0.05$. The company size variable has a significant effect with the value of $t$ count $>t$ table $(3.026>2.048)$ with a significance value of $0.006<0.05$. Based on a simultaneous study of working capital, Return on Assets (ROA), and company size influence the distribution of MSME loans to national banks in Indonesia in 2014-2018 with a $F$ table of 2.98 and a significance level of 0.05 . Then F count $>$ F table $(12.041>2.98)$ and sig. $<0.05(0,000$ $<0.05)$.

Keywords: Working Capital, Return On Assets, Company Size, MSME Credit.

\section{INTRODUCTION}

COVID-19 has a huge influence on the world's economy, the Financial System Stability Committee (KSSK) predicts that the spread of Covid-19 will hit the Indonesian economy in 2020 to reach around $2.3 \%$ to $-0.4 \%$. Micro, small and medium enterprises (MSMEs) are predicted to be hardest hit by this condition, the COVID-19 outbreak is 
different from the 1998 economic crisis in which the MSME sector spearheaded the economy. At this COVID-19 sector, the UMKM sector was the hardest hit, due to limited economic activity and the existence of a number of rules restricting economic activity. Affirmation of the role of the government that immediately formed the rules, Three forms of the laws and regulations, including Government Regulation in Lieu of Law (PERPPU) No. 1 of 2020 concerning State Financial Policies and Financial System Stability for Handling Corona Virus Disease 2019 (Covid-19) and or In the Context of Facing Threats that Harm National Economy and or Financial System Stability and Government Regulation (PP) Number 21 Year 2020 concerning Large-Scale Social Restrictions in the Context of Handling Corona Virus Disease 2019 (Covid-19). Presidential Decree No. 11 of 2020 concerning Determination of Corona Virus Disease 2019 (Covid-19) Public Health Emergency, so that MSMEs are better protected from the economic aspect.

The Banking Sector is one of the financial institutions appointed by the government in accordance with regulations issued in accordance with the COVID-19 period, which is very important to maintain the country's economic stability. Bank's role in the business world is very important to help the growth and development of the business world. Bank activities that basically sell products can indirectly grow the country's economy. The main products in the form of storage services and money lending, can help entrepreneurs in developing their business. This is no exception for small businesses, or what is currently being developed is Micro, Small and Medium Enterprises (MSMEs).

Working capital generated from banking operations activities can be a deciding factor for "good" or "bad" state of the bank. The better the bank in selling its products, the more likely it will affect working capital as well.

Return on Assets is a ratio that measures how optimal the assets of the company to generate profits. Return on Assets is calculated from total assets divided by total assets. Total assets here are a combination of current assets and fixed assets. More assets owned by banking companies are expected to be able to channel loans more optimally. But in reality, the assets owned can be obtained from problem loans. This can indirectly be a factor in the success of banks in selling their products. However, this cannot be proven without research based on banking financial data.

The size of the company might form an opinion that the larger the size of the company, the better the company in this case the banking sector in carrying out its operations. However, one thing to remember, that the banking industry is different from other business industries. This is found in obtaining fixed assets. If in non-banking companies, the addition of fixed assets can be of positive value and is good for business continuity, this is quite different from banking. Acquisition of assets in banking can go through a problem, namely the occurrence of bad loans. Assets obtained in this way are certainly not good, because they can reduce the company's performance, especially in terms of lending, especially MSME loans. But this still has to be proven in the form of research.

MSME credit which is one of the efforts to support the development of MSME is very important to be optimized. This is as explained in the first paragraph, which indirectly drives the country's economy. However, in its implementation, many factors influence the realization of MSME credit distribution, one of which is discussed in this study, namely working capital, Return on Assets, and company size. 
Previous research is used as a material for consideration and reference in this study, including ROA has no effect on lending is the result of research from Susan Pratiwi and Lela Hindasah (2014), as well as research from Suci Prihartini and I Made Dana [2018], that the influence CAR, NPL, and ROA on People's Business Credit Distribution have a significant effect.

Based on the description above, the problem of this research can be formulated how the influence of working capital on MSME credit lending, Return On Assets to MSME credit lending, company size on MSME lending, working capital, Return on Assets, and the size of MSME lending companies national banks in Indonesia as credit suppliers for Pre COVID-19, so the hope of this study as a simple analysis in evaluating the distribution of Pre Covid-19 Credit to banks in Indonesia.

\section{LITERATURE REVIEW}

\section{Definition of Working Capital}

Working capital according to Brigham and Houston, translated by Ali (2014: 258), is all short-term assets, or cash-current assets, marketable securities, inventories and trade receivables. According to Kasmir (2012: 250), working capital is capital used to carry out company operations. The formula for working capital:

$$
\text { Working Capital }=\text { Current assets }- \text { Current debt }
$$

\section{Definition of Return On Assets (ROA)}

According to Nogi S. Tangkilisan (2003: 251) Return on Assets is a measure of profitability that is better than the ratio of gross profit, operating ratio, acquisition of sales because it measures operating efficiency. This ratio shows the effectiveness of the company in using assets in accordance with its control to create revenue. The most common calculations on Return on Assets are:

$$
\text { Return on Asset }=\frac{\text { Net Provit After Tax }}{\text { Total Assets }}
$$

The greater Return on Assets shows the company's performance is getting better. That is, Return on Asset is a reflection of the effective use of assets to increase corporate profits. Something that can increase profits, is certainly seen positively for stakeholders, including creditors.

\section{Definition of Company Size (Size)}

The size of the company can be seen from the total assets owned by the company (Sujoko and Ugy, 2007: 45 in Wirawan, 2017). The size of the company is the number and type of production capacity and capabilities of the company or the number and type of services that can be provided by the company simultaneously to its customers (Niresh and Velnampy, 2014: 57 in Wirawan, 2017). Company size can be measured by the formula:

$$
\text { Size }=\text { Ln of Total Assets. }
$$




\section{Framework}

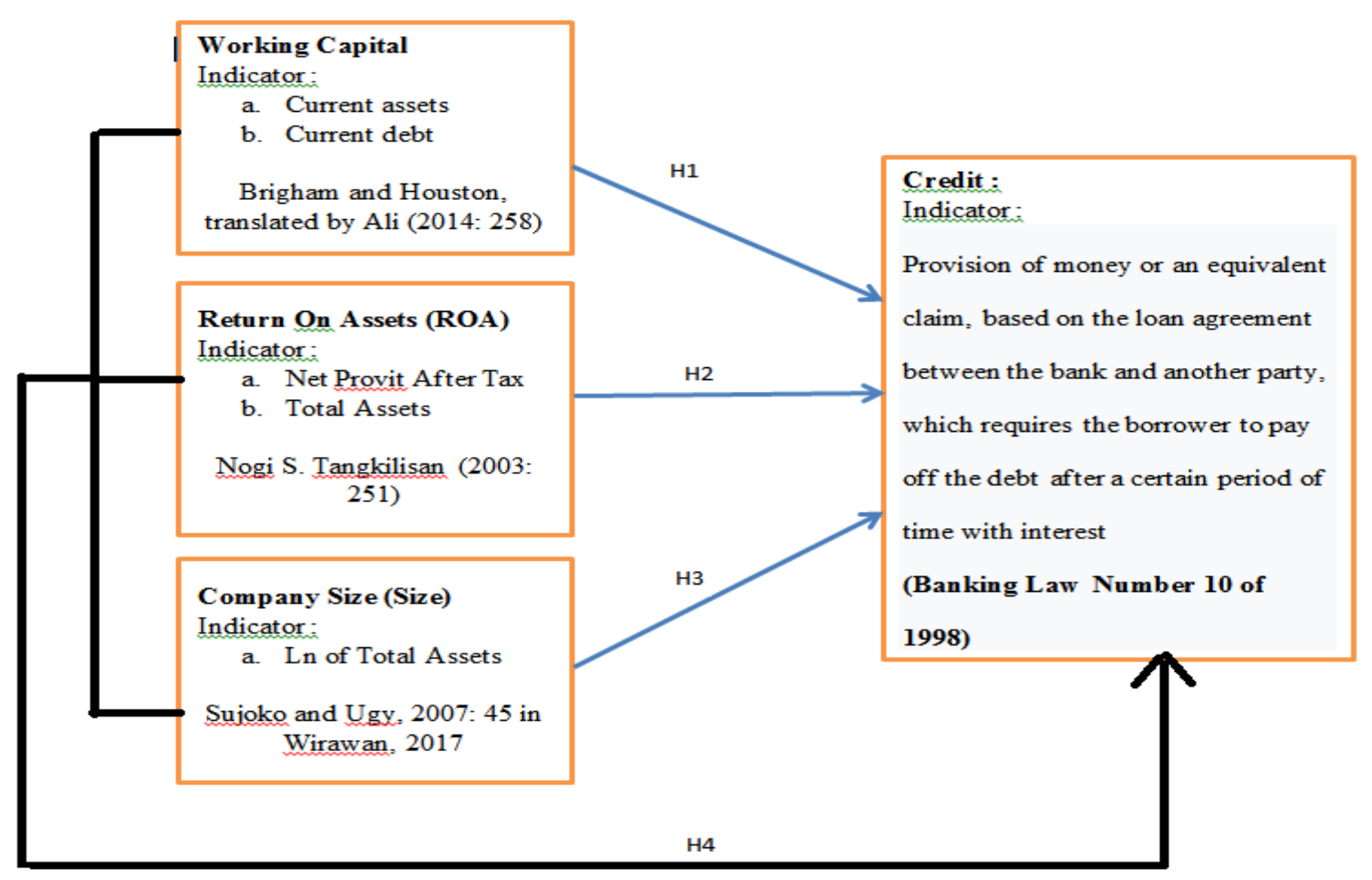

Figure 1 ; Framework For Thinking

\section{Hypothesis}

In this study, the hypothesis that the authors put forward is :

Hypothesis-1 : There is a positive influence of working capital on the distribution of MSME loans to national banks in Indonesia in 2014-2018

Hypothesis-2 : There is a positive effect of Return on Assets on the distribution of MSME loans to national banks in Indonesia in 2014-2018

Hypothesis-3 : There is a positive influence of company size on the distribution of MSME loans at national banks in Indonesia in 2014-2018

Hypothesis-4 : Simultaneously there was a positive influence between working capital, Return on Assets, and company size on the distribution of MSME loans to national banks in Indonesia in 2014-2018

\section{RESEARCH METHODS}

This research was conducted using the associative method, which is a method used to determine the effect or also the relationship between two or more variables (Sugiyono, 2014: 13). The data used in this study is quantitative data by testing associative hypotheses.

\section{Data Types and Sources}

The type of data used in this study is quantitative data in the form of financial statements of national bank companies distributing MSME credit in Indonesia Pre COVID-19 
[during 2014-2018]. Data sources used are secondary data obtained through searches of internet media from the company's official website, other sources in the form of journals needed, as well as other sources that can be used in related research.

\section{Sample and Population}

This research uses Proportionate Stratified Random Sampling method, which is a technique used if the population has members that are not homogeneous and proportionally stratified. As for the population in this study are national banking companies that distribute Pre COVID-19 MSME loans [during 2014-2018], as follows:

Tabel 1. List Of Banking Company Research Population

\begin{tabular}{cl}
\hline No. & Name Of Company \\
\hline 1 & PT. BANK RAKYAT INDONESIA (PERSERO), Tbk \\
2 & PT. BANK MANDIRI (PERSERO), Tbk \\
3 & PT. BANK NEGARA INDONESIA (PERSERO), Tbk \\
4 & PT. BANK CENTRAL ASIA, Tbk \\
5 & PT. BANK TABUNGAN NEGARA (PERSERO), Tbk \\
6 & PT. BANK DANAMON INDONESIA, Tbk \\
7 & PT. BANK TABUNGAN PENSIUNAN NASIONAL, Tbk \\
\hline
\end{tabular}

The criteria in taking the sample of this study were national banks that distributed Pre COVID-19 MSME loans [during 2014-2018].

\section{Data collection technique}

The data source used in this study is internal secondary data. Internal secondary data on the financial records of MSME credit suppliers in the form of corporate financial statements. The data source is taken from the published banking financial statements. Meanwhile, the data obtained will be processed to obtain working capital, ROA, and company size

\section{Variable Operations}

The variables used in this study consisted of independent variables and dependent variables. The independent variables in this study are working capital, Return on Assets (ROA), company size and the dependent variable in this study is the distribution of MSME loans to national banks in Indonesia Pre COVID-19 [during 2014-2018].

\section{Data Analysis Techniques}

This study uses Multiple Linear Regression analysis tools using statistical package software program SPSS (Statistical package for social science) version 25.0. The analysis technique used is Descriptive Statistics Test The classic assumption test of this study is the normality test, multicollinearity test, heteroscedasticity test, autocorrelation test. Multiple Regression Analysis and Hypothesis Test consist of Partial Test (t Test) Simultaneous Test (F Test), Determination Coefficient (Adjusted R²) 


\section{FINDINGS AND DISCUSSION \\ Descriptive statistics}

After processing the data and testing the statistics using SPSS 25, the statistical results obtained from the data variables used in this study are as follows:

Table 2. Descriptive Statistical Results

\begin{tabular}{|c|c|c|c|c|c|}
\hline \multicolumn{6}{|c|}{ Descriptive Statistics } \\
\hline & $\mathrm{N}$ & Minimum & Maximum & Mean & Std. Deviation \\
\hline Working Capital & 35 &, 22 & 2,73 & 1,1098 & ,75902 \\
\hline ROA & 35 & ,01 &, 03 & ,0210 & ,00672 \\
\hline Company Siza & 35 & 18,13 & 20,98 & 19,7857 & ,91063 \\
\hline MSME Credit & 35 & 12,19 & 19,70 & 16,6856 & 1,78556 \\
\hline $\begin{array}{l}\text { Valid N } \\
\text { (listwise) }\end{array}$ & 35 & & & & \\
\hline
\end{tabular}

Source: SPSS 25 output (data processed)

Descriptive statistical test results in table 2 above show that the amount of data or $n$ used in this study were 35 data samples taken from the financial statements of MSME credit channeling banks as many as 7 banks for the period 2014-2018.

Working capital variable has a minimum value of 0.22 , this value is owned by BTPN Bank in 2014, and a maximum value of 2.73 found in Bank Mandiri's financial statements in 2018, with a mean value of 1.1098 and a standard deviation value amounted to 0.75902 . ROA variable has a minimum value of 0.1 found in Bank Mandiri in 2016 and Bank BTN in 2014-2018 and a maximum value of 0.3 in Bank BRI and BCA in 2014-2018, with a mean value of 0.0210 and standard deviation of 0.00672. The company size variable has a minimum value of 18.13 found in BTPN Bank in 2015-2018 and a maximum value of 20.98 found in BRI Bank and Bank Mandiri in 2014-2018, with a mean value of 19.7857 and a standard deviation value amounting to 0.91063 . The MSME credit variable has a minimum value of 12.19 and a maximum value of 19.70 with a mean value of 16.66856 and a standard deviation value of 1.78556 .

\section{Normality Test}

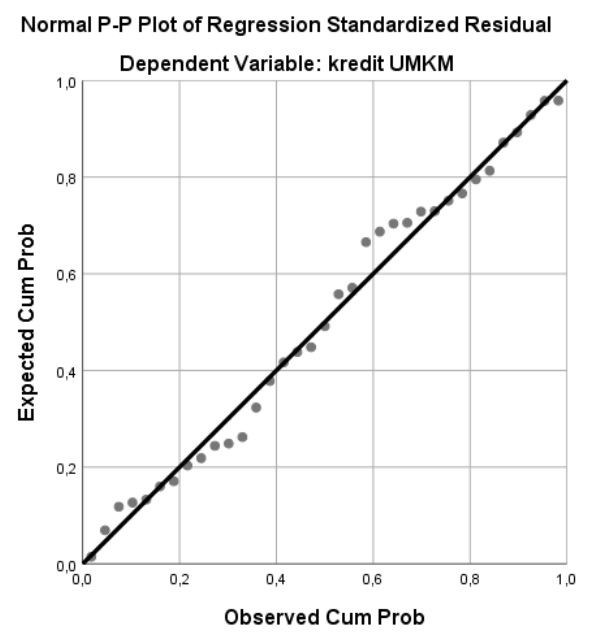




\section{Figure 2 Probability Plot Normality Test Results}

Source: SPSS 25 output (data processed)

The normality test aims to test whether in the regression model, the dependent variable, namely MSME Credit, and the independent variables namely working capital, ROA, and company size have normal data distribution or close to normal data. To test the normality of data, used the normal Probability Plot is detection by looking at the spread of data (points) on the diagonal axis on a graph.

\section{Multicollinearity Test}

This test is conducted to test whether the regression model found correlation between variables (independent). This test is done by looking at the Tolerance value and the value of Variance Inflation Factor (VIF). The cut off value commonly used to indicate multicollinearity is $<0.10$ or equal to VIF $>10$

Table 3. Multicollinearity test results with tolerance and VIF values

\begin{tabular}{|c|c|c|c|c|c|c|c|c|}
\hline \multicolumn{9}{|c|}{ Coefficients ${ }^{2}$} \\
\hline \multirow[b]{3}{*}{ Model } & & \multirow{2}{*}{\multicolumn{2}{|c|}{ Unstandardzed Cooffcionts }} & \multirow{3}{*}{$\begin{array}{c}\text { Standardized } \\
\text { Coefficients } \\
\text { Beta }\end{array}$} & \multirow[b]{3}{*}{$t$} & \multirow[b]{3}{*}{$\mathrm{sig}$} & \multirow{2}{*}{\multicolumn{2}{|c|}{ Collinearity Statstes }} \\
\hline & & & & & & & & \\
\hline & & $B$ & Std Error & & & & Tolerance & MF \\
\hline \multirow[t]{4}{*}{1} & (Constant) & 44,175 & 11,375 & & 3.883 & .001 & & \\
\hline & Working Capital & 2,852 & .710 & 1,212 & 4,016 & .000 &, 168 & 5,955 \\
\hline & ROA & 117,675 & 37,487 & .443 & 3,139 & .004 & .769 & 1,301 \\
\hline & Company Size & $-1,674$ & .625 & .854 & $-2,680$ & .012 & .151 & 6.637 \\
\hline
\end{tabular}

a. Dependent Variable: kredit UMKM

Source: SPSS 25 output (data processed)

Based on Table 3 above, the working capital variable has a Tolerance value of 0.168 , the ROA variable has a Tolerance value of 0.769 , the company size variable has a Tolerance value of 0.151 . Meanwhile, for the generated VIF value ie for the working capital variable has a VIF value of 5.955, the ROA variable has a VIF value of 1.301 , and the firm size variable has a VIF value of 6.637. In accordance with the requirements of a variable it is said to have no correlation between variables or multicollinearity does not occur ie the value of the Tolerance value $>0.10$ and the VIF value $<10$. Thus, it can be concluded that the variable under study does not have multicollinearity.

\section{Heteroscedasticity Test}

This test aims to test whether in the regression model Variance inequality occurs from the residuals of one observation to another. If the variance from one observation residual to another observation is fixed, it is called heteroscedasticity. A good regression model is one that does homoskesdasticity or does not occur heteroscedasticity. Multiple regression does not occur Heteroscedasticity if the data points spread above and below or not around the number 0 , the data points do not collect just above or below it, the spread of data points may not form a wavy pattern widened then narrowed and widened widening data points should not be patterned. The results of the SPSS version 25 heteroscedasticity test can be seen as follows: 


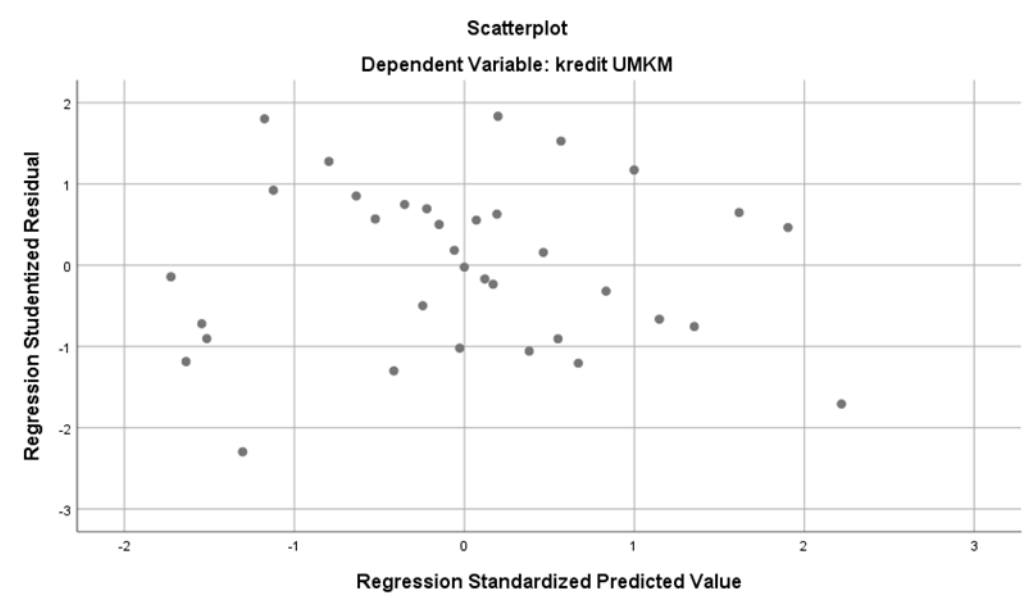

Figure 3, Heteroscedasticity Test Result

Source: SPSS 25 output (data processed)

\section{Autocorrelation Test}

The autocorrelation test aims to test whether in the linear regression model there is a correlation of confounding errors in the t period with confounding errors in the $t-1$ period (Ghozali, 2013: 107). This test uses the Durbin-Watson test to determine whether there is autocorrelation in the regression model and the following Durbin-Watson values obtained through the processing of the regression model:

Table 4. Autocorrelation Test Result

\begin{tabular}{|c|c|c|c|c|c|}
\hline Model & $\mathrm{R}$ & R Square & $\begin{array}{l}\text { Adjusted R } \\
\text { Square } \\
\end{array}$ & $\begin{array}{l}\text { Std. Error of } \\
\text { the Estimate }\end{array}$ & Durbin-Watson \\
\hline 1 & $.735 a$ & .541 & .486 & $\begin{array}{r}8015659.9871 \\
9\end{array}$ & 1.661 \\
\hline
\end{tabular}

a. Predictors: (Constant), lag_x3, lag_x2, lag_x1

b. Dependent Variable: lag_y

Coefficientsa

Table 5 . Autocorrelation Test Result

\begin{tabular}{|c|c|c|c|c|c|c|}
\hline \multirow{2}{*}{\multicolumn{2}{|c|}{ Model }} & \multicolumn{2}{|c|}{$\begin{array}{l}\text { Unstandardized } \\
\text { Coefficients }\end{array}$} & \multirow{2}{*}{$\begin{array}{l}\text { Standardized } \\
\text { Coefficients } \\
\text { Beta }\end{array}$} & \multirow[t]{2}{*}{$\mathrm{t}$} & \multirow[t]{2}{*}{ Sig. } \\
\hline & & $\mathrm{B}$ & Std. Error & & & \\
\hline \multirow{4}{*}{1} & (Constant) & 3,050 & ,968 & & 3,151 & ,004 \\
\hline & Work Capital & ,315 & ,063 & 1,488 & 4,992 & ,000 \\
\hline & ROA & ,079 & 3,117 & ,004 & ,025 & ,980 \\
\hline & Company Size &,- 161 &, 053 &,- 937 & $-3,026$ &, 006 \\
\hline
\end{tabular}

a. Dependent Variable: MSME credit

Source: SPSS 25 output (data processed) 
Based on Table 4 and Table 5 above, it shows that the DW value is 1.661 . The value obtained will be compared with the table value using a significance value of $5 \%$. The number of samples is $30(\mathrm{n}=30)$ and the number of independent variables is $3(\mathrm{k}=3)$, then in the Durbin-Watson table the lower bound value (dl) is 1.2138 and the upper limit value (du) is 1.6498. Furthermore, according to the autocorrelation rules, that a variable is declared to not occur autocorrelation if $\mathrm{du}<\mathrm{d}<4-\mathrm{du}$. Then, 1,661 <1.6498<4-1,6498. So it can be concluded that the research model does not occur autocorrelation.

\section{Multiple Linear Regression Analysis}

To measure the influence of working capital, ROA, and company size on MSME credit lending with multiple linear regression methods are as follows:

Table 6 . Multiple Linear Regression Test Result

\begin{tabular}{|c|c|c|c|c|c|c|}
\hline \multirow{2}{*}{\multicolumn{2}{|c|}{ Model }} & \multicolumn{2}{|c|}{$\begin{array}{l}\text { Unstandardized } \\
\text { Coefficients }\end{array}$} & \multirow{2}{*}{$\begin{array}{l}\text { Standardized } \\
\text { Coefficients } \\
\text { Beta } \\
\end{array}$} & \multirow[t]{2}{*}{$\mathrm{T}$} & \multirow[t]{2}{*}{ Sig. } \\
\hline & & B & Std. Error & & & \\
\hline \multirow{4}{*}{1} & (Constant) & 3,050 & 968, & & 3,151 & ,004 \\
\hline & Work Capital & ,315 &, 063 & 1,488 & 4,992 &, 000 \\
\hline & ROA & 079 & 3,117 & ,004 & ,025 & ,980 \\
\hline & Company Size &,- 161 & ,053 &,- 937 & $-3,026$ &, 006 \\
\hline
\end{tabular}

a. Dependent Variable: MSME credit

Source: SPSS 25 output (data processed)

Based on Table 6 above, the following equation can be formed:

$\mathrm{Y}=\mathrm{a}+\mathrm{b} 1 \mathrm{X} 1+\mathrm{b} 2 \mathrm{X} 2+\mathrm{b} 3 \mathrm{X} 3+\ldots$

MSME Credit $=3,050+0.315$ working capital $+0.079 \mathrm{ROA}-0.161$ company size

The regression line equation is obtained, then the regression model can be interpreted as follows, a constant coefficient (Y) of 3.050: meaning that if there is no working capital, ROA, and company size, the betas value is 3.050. It means that if the amount working capital, ROA, and company size are equal to zero, then the UMKM Credit will be 3.050. Regression coefficient X1 (working capital) has a value of 0.315 and is positive, then if the value of working capital rises by 1 percent, MSME Credit will increase by 0.513 and vice versa, if working capital falls by 1 percent then MSME Credit will decrease by 0.513 assuming working capital is considered constant. Regression coefficient X2 (ROA) has a value of 0.079 and is positive, so if the ROA value increases by 1 percent, MSME Credit will increase by 0.079 and vice versa, if ROA falls by 1 percent then MSME Credit will decrease by 0.079 assuming ROA is considered constant . Coefficient X3 (company size) has a value of -0.161 and has a negative value, so if the value of company size increases by 1 percent, MSME Credit will decrease by -0,161 and vice versa, if company size decreases by 1 percent then MSME Credit will increase by 0.161 with assuming company size is considered constant. 


\section{T test (partial)}

This test is carried out to prove whether working capital (X1), ROA (X2), and company size (X3) partially have an influence on MSME credit. The following are the results of the calculation of the $t$ test and its significance level in this study:

Table 7. T test (partial) Result

\begin{tabular}{|c|c|c|c|c|c|}
\hline \multirow[t]{2}{*}{ Model } & \multicolumn{2}{|c|}{$\begin{array}{l}\text { Unstandardized } \\
\text { Coefficients }\end{array}$} & \multirow{2}{*}{ 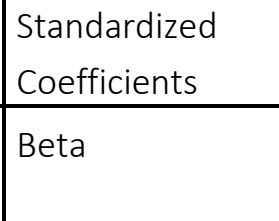 } & \multirow[t]{2}{*}{$t$} & \multirow[t]{2}{*}{ Sig. } \\
\hline & B & $\begin{array}{l}\text { Std. } \\
\text { Error }\end{array}$ & & & \\
\hline (Constant) & 3,050 & ,968 & & 3,151 & ,004 \\
\hline modal kerja & ,315 & ,063 & 1,488 & 4,992 & ,000 \\
\hline ROA & ,079 & 3,117 & ,004 & ,025 & 980 \\
\hline $\begin{array}{l}\text { ukuran } \\
\text { perusahaan }\end{array}$ &,- 161 & ,053 &,- 937 & $-3,026$ &, 006 \\
\hline
\end{tabular}

a. Dependent Variable: MSME credit

Source: SPSS 25 output (data processed)

Based on Table 7 above, it is known that $t$ calculate the working capital variable of 4.992, while for the ROA variable of 0.025 , and the company size variable of -3.026 . The hypothesis in this study is a two-way hypothesis for the t-table values obtained.

Based on the calculation above, with the amount of data (n) 35 and a significance value of 0.05 , a t-table value of 2.048 is obtained. It turns out, for the working capital variable (X1) has a value of $t$-count $>t$-table (4.992> 2.048) with a significance value of $0.000<0.05$. Thus, Ho is not accepted and $\mathrm{Ha}$ is accepted, or in other words working capital has a significant effect on the distribution of MSME Credit.

The ROA variable (X2) in the above calculation has a t-count value <t-table $(0.025$ $<2.048$ ) with a significance value of $0.980>0.05$, this means that Ho is accepted and $\mathrm{Ha}$ is not accepted, or in other words ROA has no significant effect towards MSME credit distribution.

The company size variable (X3) in the above test has a value of t-count $>$ t-table (3.026> $2,048)$ with a significance value of $0.006<0.05$, thus Ho is not accepted and Ha is accepted, or company size has an effect on MSME credit distribution. This is because the value of $t$ is absolute, that is the minus that is in the calculation results is not considered.

\section{F Test}

The F test basically shows whether all the independent variables referred to in the model have a shared influence on the dependent variable. In this test also uses a significance level of 5\% or 0.05. Calculation of the results of this test can be seen from the following table: 
Table 8. F test Result

\begin{tabular}{|l|r|r|l|l|l|}
\hline MNOVAa & \multicolumn{1}{|l|}{$\begin{array}{l}\text { Sum of } \\
\text { Squares }\end{array}$} & df & $\begin{array}{l}\text { Mean } \\
\text { Square }\end{array}$ & F & Sig. \\
\hline Regression &, 391 & 3 &, 130 & 12,041 &, $000 \mathrm{~b}$ \\
Residual &, 281 & 26 &, 011 & & \\
Total &, 672 & 29 & & & \\
\hline
\end{tabular}

a. Dependent Variable: kredit umkm

b. Predictors: (Constant), company size, ROA, capital working

Source: SPSS 25 output (data processed)

Based on Table 8 above, an F count of 12,041 was obtained with a significance value of 0,000 . With a $F$ table value of 2.98 and a significance level of 0.05 . Then $F$ count $>F$ table $(12.041>2.98)$ and sig. $<0.05(0,000<0.05)$ simultaneously there is a significant effect between the variable working capital, ROA, and company size on the distribution of MSME loans at national banks in Indonesia in the 2014-2018 period.

\section{Determination Coefficient Test}

The coefficient of determination essentially measures how far the model's ability to explain the variation of the dependent variable.

Table 9. Determination Coefficient Test Result

\begin{tabular}{lr|r|l|l|l|l}
\multicolumn{2}{l}{$\begin{array}{l}\text { Model Summaryb } \\
\text { Model R }\end{array}$} & R Square & $\begin{array}{l}\text { Adjusted R } \\
\text { Square }\end{array}$ & $\begin{array}{l}\text { Std. Error of } \\
\text { the Estimate }\end{array}$ & $\begin{array}{l}\text { Durbin- } \\
\text { Watson }\end{array}$ \\
\hline 1 & $.735 a$ & .541 & .486 & 8015659.9871 & 1.661 \\
\hline
\end{tabular}

\footnotetext{
a. Predictors: (Constant), lag_x3, lag_x2, lag_x1

b. Dependent Variable: lag_y

Source: SPSS 25 output (data processed)
}

Based on Table 9 above, obtained values for $\mathrm{R}$ Square $\left(\mathrm{R}^{2}\right)$ is 0.486 . It means that $48.6 \%$ of the MSME Credit dependent variable is explained by the working capital, ROA, and company size independent variables, while the remaining $51.4 \%$ is explained by other factors beyond the regression model that cannot be included in this study.

\section{DISCUSSION}

Based on the results of tests that have been carried out through data processing above, then in this study there are a number of things that can be explained as follows:

\section{The Effect of Working Capital on the Distribution of MSME Credit}

Based on the results of tests that have been carried out using a partial hypothesis test shows that the working capital variable (X1) does not significantly influence the MSME 
credit at national banks in Indonesia in the 2014-2018 period. This can be seen based on the results of statistical tests, that the value of $t$ arithmetic $>t$ table (4.992> 2.048) with a significance value of $0.000<0.05$. This is caused by the forming components of working capital in which there are current assets, one of which is current assets given loans. This result is in line with research conducted by Sabiela Rahmani Subekti (2010) that there is a significant influence between working capital on lending.

\section{The Effect of Return on Assets (ROA) on the Distribution of MSME Credit}

Based on the test results stated above, that partially Return on Assets (ROA) has no significant effect on MSME loans. This is evident from the statistical test results obtained, where the value of $t$ count $<t$ table $(0.025<2.048)$ with a significance value of $0.980>0.05$. This indicates that the operating efficiency measured by ROA does not affect the amount of credit extended. This is because there are a number of prioritized funding besides credit funding (Susan Pratiwi \& Lela Hindasah, 2014). This is consistent with research conducted by Susan Pratiwi and Lela Hindasah (2014) that Return on Assets (ROA) does not affect of MSME credit distribution.

\section{The Effect of Company Size on the Distribution of MSME Credit}

Based on the test results described above, that the size of the company significantly influences the distribution of MSME loans. This can be seen from the results of test calculations, that the value of $t$ arithmetic $>t$ table (3.026>2.048) with a significance value of $0.006<0.05$. This means, for each company size increase, it will increase the number of MSME loans that are distributed. The results of this study are in line with previous research conducted by Adnan, Ridwan and Fildzahc (2016) which states that a bank that has a large size means it has a large potential for wealth or funds, so as to increase the credit extended by banks.

\section{CONCLUSION AND SUGGESTION Conclusion}

Based on the results of the discussion, it can be concluded that, the working capital variable has a $t$ value $>t$ table (4.992> 2.048) with a significance value of $0.000<0.05$. Working capital variable significantly influences the distribution of MSME loans to national banks in Indonesia in 2014-2018. The Return on Assets (ROA) variable has a t value <t table $(0.025<2.048)$ with a significance value of $0.980>0.05$. The Return on Assets (ROA) variable does not affect the distribution of MSME loans to national banks in Indonesia in 2014-2018. The company size variable has a value of $t$ count $>t$ table $(3.026>2.048)$ with a significance value of $0.006<0.05$. The company size variable significantly influences the distribution of MSME loans to national banks in Indonesia in 2014-2018. Based on a simultaneous study of working capital, Return on Assets (ROA), and company size influence the distribution of MSME loans to national banks in Indonesia in 2014-2018 with a F table of 2.98 and a significance level of 0.05 . Then $F$ count $>F$ table $(12.041>2.98)$ and sig. $<0.05$ $(0,000<0.05)$. 


\section{Suggestion}

Banking holds an important role in economic growth. The large number of loans extended is expected to be able to encourage business activities both small and large scale. The amount of credit extended by banks can also be an effective indicator of a company, and can increase profits. In this case, banks are expected to increase the amount of credit for MSMEs. Because the proportion of MSME loans is only given by one of the state-owned banks, the MSME is one of the drivers of the Indonesian economy. For future researchers, who conduct research related to related variables, it is better to be able to increase the number of variables or increase the number of years of research. It also can increase the number of companies that are sampled, so that the resulting calculations can be even better.

\section{REFERENCE}

Brigham, Eugene F, dan Joel F Houston. 2011. Dasar-dasar Manajemen Keuangan. Alih bahasa : Ali Akbar Yulianto. Jakarta: Salemba Empat .

Fitriani, Dwi. 2012. Pengaruh Rasio Keuangan Bank Terhadap Penyaluran Kredit Modal Kerja. Skripsi. Padang: Universitas Andalas.

Ghozali, Imam. 2013. Aplikasi Analisis Multivariate Dengan Program SPSS 23. Semarang: Badan Penerbit Universitas Diponegoro.

Haini, Festina Nur, Irma Tyasari, dkk. 2015. Analisis Pengaruh Dana Pihak Ketiga (DPK), Non Performing Loans (NPL), dan Ukuran Perusahaan Terhadap Penyaluran Kredit Perusahaan Perbankan yang Terdaftar di Bursa Efek Indonesia. Jurnal Riset Mahasiswa Manajemen (JRMM). Universitas Kanjuruhan Malang. Malang.

Indonesia, R. (2008). Undang-Undang No. 20 Tahun 2008 tentang Usaha Mikro, Kecil, dan Menengah. Jakarta: Sekretariat Negara.

Kasmir, 2011. Dasar-dasar Perbankan. Jakarta: Raja Grafindo Persada.

Nurlestari, Annisa. 2015. Analisis Faktor-faktor yang Mempengaruhi Penyaluran Kredit UMKM. Skripsi. Semarang: Universitas Diponegoro.

Pratami, Wuri Arianti Novi. 2011. Analisis Pengaruh Dana Pihak Ketiga (DPK), Capital Adequacy Ratio (CAR), Non Performing Financing (NPF) dan Return On Asset (ROA) Terhadap Pembiayaan Pada Perbankan Syariah. Skripsi. Universitas Diponegoro. Semarang.

Pratiwi, Susan \& Lela Hindasah. 2014. Pengaruh Dana Pihak Ketiga, Capital Adequacy Ratio, Return on Asset, Net Interest Margin dan Non Performing Loan Terhadap Penyaluran Kredit Bank Umum di Indonesia. Jurnal Manajemen dan Bisnis, Vol.5 No.2 September 2014, Program Studi Manajemen Universitas Muhammadiyah Yogyakarta. Yoygakarta.

Prihantini, Suci \& I Made Dana. 2018. Pengaruh CAR, NPL, dan ROA terhadap Penyaluran Kredit Usaha Rakyat. Jurnal Manajemen, Vol. 7, No. 3, 2018: 1168-1194, No. ISSN : 2302-8912, Universitas Udayana. Bali. 
Putri, Yua Molek Winarti \& Alien Akmalia. 2016. Pengaruh CAR, NPL, ROA dan LDR Terhadap Penyaluran Kredit Pada Perbankan. Jurnal Balance. Balance Vol. XIII No. 2. Universitas Muhammadiyah Yogyakarta. Yogyakarta.

Riyanto, Bambang. 2011. Dasar-dasar Pembelanjaan Perusahaan. Edisi Empat. Yogyakarta.

Subekti, Sabiela Rahmani. 2010. Pengaruh Modal Kerja Terhadap Penyaluran Kredit Serta Dampaknya Terhadap Profitabilitas Perusahaan. Skripsi. 2019. Perpustakaan Fakultas Ekonomi dan Bisnis Unpas. Bandung.

Sugiyono. 2014. Statistika untuk Penelitian. Bandung: Alfabeta.

Tangkilisan, Hessel Nogi S. 2008. Memahami Kinerja Keuangan Perusahaan. Bandung: Alfabeta.

Tilung, Gland Mark, dkk. 2015. Pengaruh Modal Kerja dan Profitabilitas Terhadap Realisasi Kredit Pada Calon Debitur PT. Bank Mandiri (Persero) tbk Cabang Manado. Jurnal EMBA, September 2015 Vol.3 Hal.322-321, No. ISSN 2303-11, Universitas Sam Ratulangi. Manado.

Triasdini, Himaniar. 2010. Pengaruh CAR, NPL Dan ROA Terhadap Penyaluran Kredit Modal Kerja. Skripsi. Semarang: Universitas Diponegoro.

\section{Internet resources}

Badan Pusat Statistik, Berita Resmi Statistik, diakses 2 Januari 2019, <https://www.bps.go.id/website/materi_ind/materiBrsInd-20190102103608.pdf>.

Bank BRI, Tentang BRI, diakses 10 Januari 2020, <https://bri.co.id/info-perusahaan>.

Bank Central Asia, Tentang BCA, diakses pada 10 Januari 2020, https://www.bca.co.id/id/Tentang-BCA>.

Bank Indonesia, Laporan Perekonomian Indonesia 2017, diakses 2 Januari 2019,<file:///C:/Users/PC\%20Serang17/Downloads/7_LPI2017_BAB5.pdf>

Bank Mandiri, Profil Perusahaan, diakses pada 10 Januari 2020, < https://www.bankmandiri.co.id/profil-perusahaan>.

Bank Negara Indonesia, Tentang BNI, diakses pada 10 Januari 2020, < https://www.bni.co.id/idid/perusahaan/tentangbni/sejarah>.

Bank Tabungan Negara, Tentang BTN, diakses pada 10 Januari 2020, < https://www.btn.co.id/id/Tentang-Kami>.

Bank Tabungan Pensiunan Nasinal, Sekilas Tentang BTPN, diakses pada 10 Januari 2020, < https://www.btpn.com/id/tentang-kami/sekilas-btpn>. 